\title{
Súdna a disciplinárna prax v Ukrajinskej povstaleckej armáde (1943 - 1947)
}

\author{
JAROSLAV ANTONIUK - VASYL' IL'NYC'KYJ
}

Rezortný štátny archív Bezpečnostnej služby Ukrajiny - Drohobyčská štátna pedagogická univerzita Ivana Franka / Národná akadémia pozemných vojsk hajtmana Petra Sahajdačného, Ukrajina

Judicial and disciplinary practice in the Ukrainian Insurgent Army (1943 - 1947)

Abstract: The article analyzes the functioning principles of judicial and disciplinary practice in the Ukrainian Insurgent Army (UPA). It was discovered that the practice started in the summer of 1943 in Volyn and Western Polissya. At the end of that same year, the insurgent judicial system spread to Galicia as well as the neighboring territories of eastern Poland. It was proven that the main judicial and disciplinary bodies in the UPA units were the «Field Courts». At the commander's initiative, they convened for every sotnia. The verdicts were passed on the basis of the "Disciplinary Statute», which was used in conditions of the special period of armed liberation struggle. The crimes in it were divided into minor and serious. The accused were executed for the latter ones. The verdict was approved by the commander of the relevant insurgent unit. The minor offenses were mostly dealt with by the «Cossack courts». They were convened by the commanders of the insurgent units in the case of: drunkenness, non-compliance with the order without serious consequences, minor thefts. The sentences were: sending to «punitive divisions», «punitive arrest», «beating with sticks» in front of the rank, «rack under a gun» or «falling on the ground» on command. In the event the crime was repetitive, the punishment was intensified.

Keywords: Ukrainian Insurgent Army, judicial and disciplinary practice, verdict, crimes, punishments, «Field court», «Cossack courts».

DOI: https://doi.org/10.24040/ahn.2021.24.01.136-142

Vývoj európskeho súdneho systému v 20. storočí bol poznačený zložitými historickými procesmi. Ich neoddelitel'nou súčast'ou bol oslobodzovací boj a rezistencia zotročených národov v Sovietskom zväze, ktorý predpokladal fungovanie ich vlastných neštátnych súdnych a disciplinárnych orgánov. Táto prax sa najvýraznejšie prejavila vo vývoji Ukrajinskej povstaleckej armády (UPA). V súlade s vojenskými špecifikami poskytovala množstvo osobitostí.

Historiografický prehl'ad nastolenej problematiky nie je rôznorodý. Jej stručná analýza bola uskutočnená v publikáciách ukrajinských histo- 
Súdna a disciplinárna prax v Ukrajinskej povstaleckej armáde (1943 - 1947)

rikov Dmytra Vedeneeva a Hennadija Bystruchina. ${ }^{1}$ Niektoré aspekty trestného systému v UPA ozrejmil Volodymyr Serhijčuk ${ }^{2}$ a na osobitosti súdneho konania poukázal Volodymyr Koval'chuk ${ }^{3}$. Tento článok teda po prvýkrát komplexnejšie vysvetl’uje súdno-disciplinárnu prax v UPA.

Tá sa začala v lete 1943 na území Volyne a západného Polissia (v tom čase boli súčast’ou ríšskeho komisariátu „Ukrajina“), kde sa ukrajinským povstalcom podarilo oslobodit' od Nemcov vel'ké územia. Na konci tohto roku sa štruktúra UPA rozšírila do Haliče a na Zakerzonie.

Prvým disciplinárnym orgánom v povstaleckých oddieloch bol pol'ný súd. V priebehu leta - jesene 1943 neustále pôsobil na povstaleckej základni „Sič“ (Svinarynský les v rajóne Volodymyra-Volyňského). Tento pol’ný súd viedol Olexandr Kosarevyč (pseudonym „Omel'ko“), velitel’ (komandant) Vojenského pol’ného žandárstva (VPŽ) vojenského okruhu „Tury“ (Volyňská oblast’ /kraj/), a funkcie vyšetrovatel’a vykonával „Arkadij “. ${ }^{4}$ V prípade potreby bolo možné zvolat’ pol’ný súd v každej sotni ${ }^{5}$ (stotina, rota - pozn. prekl.). Dialo sa to nasledovne. Komandant VPŽ jednotky dával podnet príslušnému velitel'ovi UPA. Ten následne menoval troch sudcov. Prvý z nich musel zastávat' pozíciu nie nižšiu velitel’a sotne, druhý - nie nižšiu velitel'a družstva (ukr. - roja). VPŽ im poskytovala vyšetrovacie materiály. Rozsudok alebo „Výrok“ potvrdzoval velitel’ oddielu. ${ }^{6}$ Na území Peremyšl'ského okruhu Organizácie ukrajinských nacionalistov (OUN) pol’ný súd pozostával z velitel'a sotne, velitel'a VPŽ a dôstojníka Bezpečnostnej služby (BS). Okrem toho sa počítalo aj s obhajcom obvineného.7

\footnotetext{
1 ВєДЄНЄЄВ, Д.: Військово-польова жандармерія - спеціальний орган Української повстанської армії // Воєнна історія, 2002, № 5-6, с. 32-40; ВЄДЄНЄЄВ. Д. - БИСТРУХІН, Г.: Меч і тризуб. Розвідка і контррозвідка руху українських націоналістів та УПА (1920 1945). Київ: Генеза, 2006, с. 210-211; ВЄДЄНЄЄВ, Д. - БИСТРУХІН, Г.: Двобій без компромісів. Протиборство спецпідрозділів ОУН та радянських сил спецоперацій. 1945 - 1980ті роки. Київ: К.І.С., 2007, с. 432; ВЄДЄНЄЄВ, Д. - БИСТРУХІН, Г.: «Повстанська розвідка діє точно й відважно...». Документальна спадщина підрозділів спеціального призначення ОУН та УПА. 1940 - 1950-ті роки. Київ: К.І.С., 2008, с. 38.

2 СЕРГІЙЧУК, В.: ОУН-УПА в роки війни: нові документи і матеріали. Київ: Дніпро, 1996. $496 \mathrm{c}$.

${ }^{3}$ КОВАЛЬЧУК, В.: Протоколи допитів у системі документообігу Організації Українських Націоналістів (Б) і Української повстанської армії (1940-1944рр.) // Воєнна історія, 2008, 5 (41), с. 75-80.

${ }^{4}$ Архів Управління СБУ у Волинській області (Archív Správy Bezpečnostnej služby Ukrajiny /BSU/vo Volyňskej oblasti). - Ф. 4. - Спр. 2976. - Арк. 85.

5 Галузевий державний архів Служби безпеки України - ГДА СБУ (Rezortný štátny archív Bezpečnostnej služby Ukrajiny). - Ф. 65. - Оп. 1. - Спр. С-9109. - Т. 2. - Арк. 61.

${ }^{6}$ Архів Управління СБУ у Волинській області. - Ф. 5. - Спр. 8054. - Арк. 72; ГДА СБУ. Ф. 62. - Оп. 4. - Спр. 29. - Арк. 335.

${ }^{7}$ BROŻYNIAK, A.: Uwagi o pracy Służby Bezpieczeństwa Organizacji Ukraińskich Nacjonalistów w świetle sprawozdania referenta I okręgu OUN za maj-czerwiec 1945 roku. In: Pamięć i Sprawiedliwość, 2006. 5/1 (9), s. 388.
} 
Podl'a Disciplinárneho štatútu UPA sa za závažné trestné činy považovali: 1) zrada, 2) sabotáž, 3) nedodržanie nariadenia, ktoré viedlo $\mathrm{k}$ značným stratám, 4) opakovaná dezercia. Obvinení z týchto činov boli zväčša popravovaní. ${ }^{8}$ Napríklad väčšina rozhodnutí pol'ných súdov skupiny UPA „Zahrava“ (Rivnenská oblast') sa týkala opakovaných dezercií z UPA. ${ }^{9}$ Avšak na prísne tresty boli častokrát odsúdení aj zlodeji a podozriví zo spolupráce s nepriatel'om. ${ }^{10}$ Tak na jar roku 1944 na území Ostrohského rajónu (okresu) Rivnenskej oblasti bol popravený povstalec, ktorý ukradol bravčovú mast' u gazdu, čím pred miestnou českou komunitou skompromitoval vlastnú sotňu UPA. ${ }^{11} \mathrm{~V}$ decembri 1944 sa počas boja s jednotkami NKVD pokúsil strelec „Obuch“ zastrelit’ velitel'a sotne UPA „Morozenka“. Jeho prípad vyšetrovala VPŽ. Počas výsluchu sa „Obuch“ priznal, že vykonával úlohu vedúceho Lanoveckého okresného oddelenia NKVD. Bol vynesený rozsudok - „za zradu UPA“ popravit’ zastrelením pred nastúpenými povstalcami. ${ }^{12}$

Pri výkone popráv existovali niektoré regionálne rozdiely. Napríklad na severe Rivnenskej oblasti v skupine UPA Petra Olijnyka („Eneja“) sa vyskytovali prípady odsúdenia st'atím hlavy a to pred nastúpenými povstalcami. ${ }^{13}$ Takéto rozsudky boli vynesené: vedúcemu spojovacej skupiny Mykolovi Martynovskému („Mucha“), ${ }^{14}$ povstalcovi „Tymošenkovi“ z ochranky „Eneja“.15 Dňa 26 novembra 1943 - vojakovi „Ryzykantovi“ z oddielu UPA „Lajdaky“ (Dubrovyckij rajón /okres/).16 V apríli 1944 - povstalcovi z oddielu „Kory“ (Volodymyreckij rajón). ${ }^{17}$

Medzi právomoci pol'ného súdu patrilo posudzovanie prípadov nielen bežných povstalcov, ale aj velitel'ov oddielov UPA. Jedným z častých obvinení boli chybné rozhodnutia v bojovej situácii. Napríklad neúspešné ostrel'ovanie nemeckej posádky mesta Mizoč v regióne Zdolbunova v septembri 1943 delostreleckou čatou UPA „Berezy“. Napriek tomu, že delá striel'ali z takticky výhodného miesta, zasiahnut' ciele sa

\footnotetext{
8 ГДА СБУ. - Ф. 65. - ОП. 1. - Спр. С-9109. - Т. 1. - Арк. 62; СЕРГІЙЧУК, В.: ОУН-УПА в роки війни. Нові документи і матеріали. К.: Дніпро, 1996, с. 272-274.

9 КОВАЛЬЧУК, В.: Протоколи допитів у системі документообігу Організації Українських Націоналістів ОУН (б) і Української Повстанської Армії (1940 - 1944 рр.) // Воєнна історія, 2008, 5 (41), с. 79.

${ }^{10}$ ГДА СБУ. - Ф. 65. - Оп. 1. - Спр. С-8467. - Т. 1. - Арк. 125.

${ }^{11}$ Архів Управління СБУ в Рівненській області (Archív Správy Bezpečnostnej služby Ukrajiny /BSU/v Rivnenskej oblasti). - Ф. 4. - Спр. 10406. - Арк. 90.

12 Архів Управління СБУ в Тернопільській області (Archív Správy Bezpečnostnej služby Ukrajiny /BSU/v Ternopil'skej oblasti). - Ф. 6. - Спр. 19299. - Арк. 29.

${ }^{13}$ Архів Управління СБУ в Рівненській області. - Ф. 5. - Спр. 12247. - Арк. 15.

14 ГДА СБУ. - Ф. 65. - Оп. 1. - Спр. С-9219. - Т. 1. - Арк. 231.

15 ГДА СБУ. - Ф. 6. - Оп. 1. - Спр. 72945. - Арк. З3зв.

16 ГДА СБУ. - Ф. 5. - Оп. 1. - Спр. 67961. - Арк. 65зв.

17 Архів Управління СБУ в Рівненській області. - Ф. 5. - Спр. 1148. - Арк. 22. 
nepodarilo. ${ }^{18}$ V marci 1944 sa konal pol'ný súd nad velitel'om „Kryvym“, ktorý l'ahkovážne umiestnil svoj oddiel ned'aleko mesta Brody a bol palebne napadnutý Nemcami. ${ }^{19} \mathrm{~V}$ takýchto prípadoch sa spravidla uplatňovali disciplinárne sankcie. Na jeseň roku 1945 sa na území Oleského rajónu L'vovskej oblasti uskutočnil pol'ný súd nad velitel'om sotne UPA „Opokojom“. Na základe obvinenia zo zbabelosti počas boja bol degradovaný na radového strelca. ${ }^{20}$

Ovel'a prísnejšie sa trestalo nedodržiavanie alebo porušovanie príkazu. Dňa 6. marca 1944 pol'ný súd prerokoval prípad velitel'a kureňa (práporu - pozn. prekl.) UPA Porfirija Antoniuka („Klišča“). Obvinili ho z neoprávnených rokovaní s Nemcami. Súdu predsedal „Omel'ko” a členmi boli propagandista „Zoloteranko” a velitel’ sotne „Letun”. Prípad sa prerokoval v priebehu dňa. Podl'a výroku pol'ného súdu bol velitel' „Klišč“ odsúdený na popravu s právom odvolania sa do 24 hodín po vyhlásení verdiktu. ${ }^{21}$ Dňa 21. marca 1944 bol pre paniku a odmietnutie splnit' príkaz predislokácie na Polissia popravený Hryhorij Kuzma („Moroz“) - velitel’ kureňa UPA „Pohrom“.22 Obvinenia z nedodržania príkazu sa však nie vždy končili popravou. Napríklad obvinený z rokovania s Nemcami Ivan Veresiuk („Ivančuk“), vedúci výcvikového oddelenia štábu UPA-Západ, bol spod obžaloby oslobodený. ${ }^{23}$ Velitel' sotne UPA „Čorni čorty“ (oblast' Kolomyje) Mychajlo Draban („Don“) bol v januári 1944 odvolaný z funkcie na tri mesiace. ${ }^{24}$ Podobný trest za nedodržanie rozkazu dostal aj velitel' Kremeneckého kureňa UPA Ivan Klymyšyn („Kruk“). ${ }^{25}$ Posledné pol'né súdy pôsobili pri povstaleckých kureňoch UPA na Zakerzoní až do jesene 1947.26

Prevažne l'ahšími zločinmi a deliktmi medzi vojakmi UPA sa zaoberali hlavne tzv. kozácke súdy, ktoré boli prvýkrát zavedené nariadením Hlavného vojenského štábu UPA č. $2 / 43$ z 18. decembra 1943. ${ }^{27}$ Kozácke súdy

\footnotetext{
18 МАРЧУК, І. - ТИЩЕНКО, О.: УПА. Гурби: квітень 1944-го. Видання четверте, доповнене. Рівне: Видавництво Олега Зеня, 2007, с. 163.

${ }^{19}$ ГДА СБУ. - Ф. 5. - Оп. 1. - Спр. 50970. - Т. 1. - Арк. 197.

${ }^{20}$ ГДА СБУ. - Ф. 71. - Оп. 7. - Спр. 5. - Арк. 96.

${ }^{21}$ ГДА СБУ. - Ф. 13. - Оп. 1. - Спр. 376. - Т. 54. - Арк. 1.

22 Літопис УПА. Нова серія. Т. 14: УПА і запілля на ПЗУЗ 1943-1945. Нові документи. Упоряд.: В. Ковальчук, І. Марчук. Київ; Торонто: Літопис УПА, 2010, с. 116.

${ }^{23}$ ГДА СБУ. - Ф. 6. - ОП. 1. - Спр. 74268. - Арк. 177.

${ }^{24}$ Архів Управління СБУ у Львівській області (Archív Správy Bezpečnostnej služby Ukrajiny /BSU/v L'vivskij oblasti). - Ф. 5. - Спр. 35197. - Арк. 13.

25 ДАНИЛЮК, М.: Повстанський записник. Нью-Йорк; Джерсі-Сіті: Свобода, 1968, с. 280.

${ }_{26}$ ГДА СБУ. - Ф. 65. - Оп. 1. - Спр. С-9108. - Т. 2. - Арк. 61-62; Спр. С-9109. - Т. 1. - Арк. 62.

27 ГДА СБУ. - Ф. 6. - Оп. 1. - Спр. 74268. - Т. 2. - Арк. 13зв; ВЄДЄНЄЄВ, Д.: Військовопольова жандармерія - спеціальний орган Української Повстанської Армії // Воєнна історія, 2002, № 5-6, с. 35.
} 
zvolali velitelia povstaleckých jednotiek. ${ }^{28}$ Medzi ich kompetencie patrilo prešetrenie: 1) opitosti; 2) nevykonania príkazu, ktoré neviedlo $\mathrm{k}$ vážnym následkom; 3) menších krádeží. ${ }^{29}$ Väčšinou kozácke súdy odsudzovali na 10 - 20 úderov bukmi (palicami) pred nastúpenými povstalcami. ${ }^{30}$ V sotni UPA „Orla“, pôsobiacej v oblasti Kovel'a, používali sa tresty ako: „doliv“ - padnutie na povel tridsat'krát na zem, „státie v pozore" so zbraňou (puškou) od 10 minút do hodiny, „šompolovanie“ - 10 - 25 úderov „šompolom“ (z pušky) pred nastúpenými povstalcami. ${ }^{31} \mathrm{Na}$ príklad za nedodržanie príkazu strelec VPŽ Dmytro Hrycko („Ciapka“) bol odsúdený na 48 hodín „státia“ so zbraňou a spojka Jaroslav Hluch z obce Slávna Zborovského rajónu Ternopil'skej oblasti - na 10 úderov palicou. ${ }^{32} \mathrm{Ak}$ bol obvinený súdený druhýkrát, trest sa zintenzívňoval a presúval na pol'ný súd. $V$ takom prípade sa popravovalo aj za relatívne menšie previnenia. Napríklad v sotni UPA Mychajla Kučery („Jara“) z Taktickej skupiny „Lemko“ (na Lemkovine) boli odsúdení na popravu traja povstalci, ktorí trpeli pohlavnými chorobami. ${ }^{33}$

Jedným z druhov disciplinárnych trestov za l'ahšie trestné činy bolo zasielanie $\mathrm{k}$ tzv. trestným oddielom. Odsúdení povstalci vykonávali $\mathrm{v}$ nich najt'ažšiu prácu a boli na osobitnej strave, ktorú pre nich vypracoval hospodársky referent. ${ }^{34}$ Pôsobenie trestných oddielov sa predpokladalo pri VPŽ každého oddielu UPA. Ich hlavnou úlohou bolo posilnenie disciplíny povstalcov. Tak strelec Fedor Bezuško („Burčak“), ktorý stratil pušku, bol najskôr prinútený ju nájst'. Následne bol odoslaný do trestného oddielu jednotky UPA Makara Mel'nyka („Kory“) pôsobiacej v okolí Sarn. ${ }^{35} \mathrm{Na}$ jeseň 1943 strelec Hryhorij Pastušok („Sokil“) ušiel z poddôstojníckej školy v obci Močulky Turijského rajónu na Volyni. Neskôr ho doma zatkli príslušníci BS a bol poslaný do trestnej sotne na Polissi. Po odpykaní si dvojmesačného trestu bol „Sokil“ zaradený do sotne UPA „Siromachy". ${ }^{6}$ V decembri 1943 strelec UPA Mykola Kviatkovskyj v opitom stave bezdôvodne zahájil pal'bu. Nato sa pokúsil dezertovat' a zajal ho

${ }^{28}$ ГДА СБУ. - Ф. 6. - Оп. 1. - Спр. 74268. - Т. 2. - Арк. 13 зв.

${ }^{29}$ ГДА СБУ. - Ф. 65. - ОП. 1. - Спр. С-8707. - Арк. 11-22; СЕРГІЙЧУК, В.: ОУН-УПА в роки війни. Нові документи і матеріали. К.: Дніпро, 1996, с. 275-277.

30 Архів Управління СБУ в Тернопільській області. - Ф. 6. - Спр. 19299. - Арк. 29.

31 Архів Управління СБУ у Волинській області. - Ф. 4. - Спр. 10584. - Арк. 193.

32 ГДА СБУ. - Ф. 73. - ОП. 1. - Спр. 14. - Арк. 18; Горить ліс! Спомини колишнього вояка УПА. Лондон: Українська видавнича спілка, 1975, с. 66.

${ }^{33}$ ГДА СБУ. - Ф. 62. - Оп. 4. - Спр. 17. - Арк. 10; SAMВОRSKI, M.: Służba Bezpieczeństwa w tzw. Zakierzońskim kraju OUN-SD. Sposób organizacji i obsada kadrowa. In: Dzieje najnowsze, Rocznik XLV, 2013, 1, s. 98.

${ }_{34}$ СЕРГІЙЧУК, В.: ОУН-УПА в роки війни. Нові документи і матеріали. К.: Дніпро, 1996, c. 275.

35 Архів Управління СБУ в Рівненській області. - Ф. 4. - Спр. 68144. - Арк. 11.

${ }^{36}$ Архів Управління СБУ у Волинській області. - Ф. 5. - Спр. 1577. - Арк. 13. 
oddiel BS Poryckého rajónu OUN. Pol'ný súd v obci Mokrec (v rajóne Volodymyra-Volyňského) ho odsúdil na trest smrti. Rozsudok bol však čoskoro zmenený na štyri týždne pôsobenia v „trestnej“ sotni „Holuba“, ktorá sa nachádzala v ned'alekej obci Stavky. ${ }^{37}$

Je známa aj existencia špeciálnych tzv. trestných táborov pre odsúdených povstalcov UPA. Jeden z nich pôsobil v lete - jeseni 1943 pri VPŽ skupiny UPA „Tury“ pod velením Alexandra Kosarevyča („Omel'ka“) na „Siči“ vo Svinarynskom lese v rajóne Volodymyra-Volyňského. ${ }^{38}$ Začiatkom roku 1944 v pôsobností štábu UPA-Sever na Polissi pôsobil trestný tábor „Kentaurus“. ${ }^{39}$ Disciplinárne tresty vykonávané prostredníctvom trestných oddielov sa najčastejšie uplatňovali na Volyni a v západnom Polissi, aj ked' v niektorých prípadoch sa objavovali i v Haliči. Tak velitel' BS Terebovlianskeho rajónu Stepan Sytnyk („Mak“) v novembri 1943 zadržal člena OUN Josypa Hlovackého. Po výsluchu bol poslaný do trestnej sotne UPA. ${ }^{40}$

Existovala taktiež sankcia „trestného uväznenia“ (domáceho väzenia) pri oddiele UPA. Odsúdený mal vtedy zakázané fajčit', čítat', hrat' a spievat'. „Trestné uväznenie“ bolo rozdelené do niekol'kých typov: 1) obyčajné (stav ako u iných povstalcov), 2) st'ažené (odpočinok len na tvrdej posteli), 3) t’ažké (odsúdený dostával v priebehu dvoch dní 200 gramov chleba a liter vody a len na tretí deň varenú stravu; cez deň mu bolo zakázané ležat' alebo sediet'; bola povolená iba jedna prechádzka denne trvajúca do 15 minút; v noci od 22.00 do 5.00 mu bol poskytnutý odpočinok v chladnej miestnosti s tvrdou postel'ou). ${ }^{41}$ Za porušenie doby „opušt'áka“ bol strelec Fedir Bezuško („Burčak“) z obce Dubivka Volodymyreckého rajónu odsúdený na mesiac „trestného uväznenia“. Počas výkonu trestu musel každý deň behat', plazit' sa po zemi a pochodovat'. Neskôr bol „Burčakovi“ umožnený návrat domov a bol ustanovený za velitel'a stanice BS. 42

Takže hlavnými súdno-disciplinárnymi orgánmi v jednotkách UPA boli pol'né súdy. V prípade potreby boli zvolávané pri každej sotni. Predpokladalo sa, že jeden z troch sudcov pol'ného súdu bude mat' funkciu nie nižšiu velitel'a sotne, druhý - velitel’a družstva. Rozsudky sa vynášali na

\footnotetext{
${ }^{37}$ Архів Управління СБУ у Волинській області. - Ф. 4. - Спр. 23018. - Т. 2. - Арк. 2-3.

${ }^{38}$ Архів Управління СБУ у Волинській області. - Ф. 4. - Спр. 2976. - Арк. 86.

${ }^{39}$ ВЄДЄНЄЄВ, Д. - БИСТРУХІН, Г.: Меч і тризуб. Розвідка і контррозвідка руху украйнських націоналістів та УПА (1920 - 1945). Київ: Генеза, 2006, с. 300; ОУН і УПА в 1944 році: Документи. В 2 ч. Ч. 1. Упорядники: О. Веселова, О. Кокін, О. Лисенко, В. Сергійчук. Київ: Інститут історії НАН України, 2009, с. 29.

40 Архів Управління СБУ в Тернопільській області. - Ф. 6. - Спр. 4966. - Арк. 263.

${ }^{41}$ СЕРГІЙЧУК, В.: ОУН-УПА в роки війни. Нові документи і матеріали. К.: Дніпро, 1996, c. $276-277$.

${ }^{42}$ ГДА СБУ. - Ф. 5. - Оп. 1. - Спр. 68144. - Арк. 94.
} 


\section{Jaroslav Antoniuk - Vasyl Il'nyc'kyj}

základe Disciplinárneho štatútu UPA. Podl’a neho boli zločiny rozdelené na l'ahké a závažné. Posledné zahŕňali: zradu, sabotáž, nedodržiavanie nariadenia, ktoré viedlo k výrazným stratám, opakovanú dezerciu. Obvinení zo závažných trestných činov boli väčšinou popravení. Verdikt poI'ného súdu potvrdzoval velitel' príslušnej povstaleckej jednotky.

Lahšími previneniami sa zvyčajne zaoberali „kozácke súdy“. Zvolali ich velitelia povstaleckých oddielov v prípade opitosti, nedodržania rozkazu (bez vážnejších následkov), drobných krádeží. Formou trestu bolo: odosielanie do trestných oddielov, trestné uväznenie, „šompolovanie“ pred nastúpenými povstalcami, „státie v pozore“ so zbraňou alebo padanie „doliv“ na povel. V prípade opakovaného stíhania sa tresty zvyšovali vrátane popravy.

Preklad z ukrajinčiny Michal Šmigel' 